\title{
Antibacterial power effectiveness of calcium hydroxide and propolis mixture on Fusobacterium nucleatum bacteria
}

\author{
Ira Widjiastuti ${ }^{1}$, Sukaton$^{1}$, Agnes Melinda Wong ${ }^{2}$, Nanik Zubaidah ${ }^{1}$ \\ ${ }^{1}$ Department of Conservative Dentistry, Faculty of Dental Medicine Faculty, Universitas Airlangga, Surabaya, Indonesia \\ ${ }^{2}$ Undergraduate Student of Dental Medicine Faculty, Universitas Airlangga, Surabaya, Indonesia
}

\begin{abstract}
Background: Calcium hydroxide is a root canal dressing material that is widely used in dentistry because of its ability to regenerate hard tissue and eliminate bacteria. According to Ferreira et al. (2015), Fusobacterium nucleatum was found in $90 \%$ of teeth that had a root canal treatment done using calcium hydroxide as an intracanal medication. Due to this shortcoming of the antibacterial power of calcium hydroxide, additional research on alternative ingredients that can be combined with calcium hydroxide to improve its antibacterial power is necessary. Propolis is a natural material that has high antibacterial power and has long been used in dentistry. The addition of propolis to calcium hydroxide is expected to improve the antibacterial power of calcium hydroxide without eliminating its function in terms of regenerating hard tissue. Purpose: To find out how effective is the antibacterial power of a combination of calcium hydroxide and propolis against Fusobacterium nucleatum. Methods: The research was carried out using 4 treatment groups consisting of 6 samples for each group. Group 1 is given a combination of calcium hydroxide and propolis with a ratio of 1:1, group 2 with a ratio of 1:1.5, group 3 with a ratio of 1:2, and group 4 is a positive control of calcium hydroxide and sterile aquadest suspension. Each sample was put into a test tube containing BHIB and a suspension of Fusobacterium nucleatum, incubated at $37^{\circ} \mathrm{C}$ for 24 hours, and vortexed for 1 minute. A total of $0.1 \mathrm{ml}$ of bacterial inoculum was taken from each sample and then put into the MHA and grown for 24 hours. The number of Fusobacterium nucleatum colonies grown on MHA was calculated and expressed using the Colony Forming Unit (CFU). Results: There were fewer colonies of Fusobacterium nucleatum in the treatment group compared to the control group. Conclusion: The combination of calcium hydroxide and propolis has an effective antibacterial power against Fusobacterium nucleatum which the ratio of 1:2 is more effective than ratio of $1: 1,5$ and $1: 1$.
\end{abstract}

Key words: calcium hydroxide, propolis, Fusobacterium nucleatum.

Correspondence: Dr. Ira Widjiastuti, drg., M.Kes., Sp.KG (K), Dental Medicine Faculty, Airlangga University, Surabaya Indonesia, +6287854573451, ira-w@ fkg.unair.ac.id

\section{INTRODUCTION}

Dental caries is recognized as the main problem of oral health and the main cause of tooth $\operatorname{loss}^{1}$. Based on the data of Riset Kesehatan Dasar (Riskesdas) in 2013, the prevalence of active caries in the Indonesian population showed a significant percentage of $53.2 \%$. Dental caries refers to local damage of dental hard tissue by acid products as a result of bacterial fermentation of carbohydrate diets, which generally start from enamel to dentine. It is not uncommon for caries on the enamel and dentine to continue to cause pulp necrosis and dental root canal infection as a result of continuous bacterial invasion $^{2}$

For teeth with pulp necrosis, dental root canal treatment (RCT) is needed which aims to maintain the presence of teeth in the oral cavity with one of the treatment procedures is root canal sterilization with the application of dressing ${ }^{3}$. The use of dressing material on RCT aims to reduce the number of bacteria and prevent bacterial regrowth, reduce pain, induce hard tissue regeneration, and reduce tooth apex resorption. From many various types of RCT dressing materials, calcium hydroxide is one of the materials widely used in dentistry nowadays ${ }^{2}$.

Calcium hydroxide with the formula $\mathrm{Ca}(\mathrm{OH})_{2}$ is a strong base with a $\mathrm{pH}$ of 12.5-12.8 after contact with solvent media and dissociates into calcium $\left(\mathrm{Ca}^{2+}\right)$ and hydroxyl ions $\left(\mathrm{OH}^{-}\right)$. As a RCT dressing material, $\mathrm{Ca}^{2+}$ from $\mathrm{Ca}(\mathrm{OH})_{2}$ acts to induce the formation of dentine, while $\mathrm{OH}^{-}$plays a role in increasing $\mathrm{pH}$ to be a strong base that can cause bacterial death by damaging its cell wall. These things placed $\mathrm{Ca}(\mathrm{OH})_{2}$ as the ideal $\mathrm{RCT}$ dressing material because it has two main functions that are important for the treated dental root canal, which are regeneration of dental hard tissue and elimination of bacteria ${ }^{4}$. However, the antibacterial power of $\mathrm{Ca}(\mathrm{OH})_{2}$ was declared weakened as the $\mathrm{pH}$ decreased which occurred some time after $\mathrm{Ca}(\mathrm{OH})_{2}$ was dissociated ${ }^{5}$. The weakness of the antibacterial power of $\mathrm{Ca}(\mathrm{OH})_{2}$ is proven through research conducted by Ferreira et al. (2015) which showed that Fusobacterium nucleatum was 
found with a percentage of $90 \%$ in teeth with RCT with $\mathrm{Ca}(\mathrm{OH})_{2}$ as an intracanal medication ${ }^{7}$.

Fusobacterium nucleatum is a rod-shaped or spindle Gram-negative bacterium, anaerobic, non-motile, has little fimbriae or pili, does not form spores ${ }^{8}$. F. nucleatum was found as one of the Gram-negative bacteria found in teeth with pulp necrosis and root canal infection, supported by studies conducted by Fabris et al. (2014) which showed that $F$. nucleatum was found in as many as $25 \%$ in 88 of 103 dental samples that had pulp necrosis. This species has been shown to be able to survive even after the root canal of the tooth is permanently filled with sealers and gutta percha ${ }^{9}$.

The weakness of the antibacterial power of $\mathrm{Ca}(\mathrm{OH})_{2}$ requires research related to other material that can be combined with $\mathrm{Ca}(\mathrm{OH})_{2}$ to increase its antibacterial power without reducing the ability to regenerate dental hard tissue. Propolis is a natural substance which can be combined with $\mathrm{Ca}(\mathrm{OH})_{2}$ without causing toxicity. Propolis is a resin substrate, collected by bees from leaf buds and plant bark mixed with enzymes and wax from honeycomb. Various contents of propolis include vitamins (A, B, and $\mathrm{C}$ ), minerals ( $\mathrm{Ca}, \mathrm{Mg}, \mathrm{Na}, \mathrm{Fe}, \mathrm{Mn}$, $\mathrm{Cu}$, and $\mathrm{Zn}$ ), succinate dehydrogenase enzymes, as well as various active substances namely polyphenols (flavonoids, phenolic acids, and esters), terpenoids, steroids, and amino $\operatorname{acids}^{10}$. Biological and pharmacological activities of broad-spectrum propolis with their role as antibacterial, antiviral, antioxidant, anti-inflammatory, antifungal, antiprotozoal, anesthetic, antitoxic, immuno-stimulator, anti-tumor and healing ${ }^{11}$.

Various advantages of propolis are expected to be able to improve the lack of $\mathrm{Ca}(\mathrm{OH})_{2}$ antibacterial power so that the research is conducted to determine the effectiveness of the antibacterial combination of calcium hydroxide and propolis against the Fusobacterium nucleatum bacteria.

\section{MATERIALS AND METHODS}

This study was a laboratory experimental study using Fusobacterium nucleatum ATCC 25586 as the study sample. The number of samples is determined by calculating the Federer formula so that this study uses 6 samples for each treatment.

The study was initiated by creating a culture of Fusobacterium nucleatum ATCC 25586, started by taking a bacterial culture using osseous wire and put it into a test tube containing $5 \mathrm{ml}$ of Brain Heart Infusion Broth (BHIB) then incubating it in an anaerobic jar at $37^{\circ} \mathrm{C}$ for 24 hours. The $F$. nucleatum culture that had grown on BHIB was then standardized with $0.5 \mathrm{Mc}$ Farland.

Besides preparing bacterial samples, a combination of $\mathrm{Ca}(\mathrm{OH})_{2}$ and propolis prepared with a ratio of $1: 1$ which consist of $0.125 \mathrm{~g}$ of $\mathrm{Ca}(\mathrm{OH})_{2}$ powder and 0.125 $\mathrm{ml}$ of propolis extract, a ratio of 1:1.5 consist of $0.125 \mathrm{~g}$ of $\mathrm{Ca}(\mathrm{OH})_{2}$ powder and $0.1875 \mathrm{ml}$ of propolis extract, a ratio of $1: 2$ consist of $0.125 \mathrm{~g}$ of $\mathrm{Ca}(\mathrm{OH})_{2}$ powder and $0.25 \mathrm{ml}$ of propolis extract, and as a control group which is the mixture of $\mathrm{Ca}(\mathrm{OH})_{2}$ powder with sterile distilled water.

After preparing the research material, four test tubes were provided; the first tube contains $5 \mathrm{ml} \mathrm{BHIB}+0.1$ $\mathrm{ml}$ of Fusobacterium nucleatum ATCC $25586+$ combination of $\mathrm{Ca}(\mathrm{OH})_{2}$ and propolis $1: 1$; the second tube contains $5 \mathrm{ml} \mathrm{BHIB}+0.1 \mathrm{ml}$ of Fusobacterium nucleatum ATCC 25586 + combination of $\mathrm{Ca}(\mathrm{OH})_{2}$ and propolis $1: 1.5$; the third tube contains $5 \mathrm{ml} \mathrm{BHIB}+0.1$ $\mathrm{ml}$ of Fusobacterium nucleatum ATCC $25586+$ combination of $\mathrm{Ca}(\mathrm{OH})_{2}$ and propolis $1: 2$; and the fourth tube as a positive control containing $5 \mathrm{ml} \mathrm{BHIB}+0.1 \mathrm{ml}$ of Fusobacterium nucleatum ATCC $25586+\mathrm{Ca}(\mathrm{OH})_{2}$ suspension. The four tubes were incubated in anaerobic jar at $37^{\circ} \mathrm{C}$ for 24 hours, then vortexed for 1 minute. The cultures of Fusobacterium nucleatum ATCC 25586 in the four tubes were taken as much as $0.1 \mathrm{ml}$ of bacterial inoculum using a micropipette, then flattened on a petridisk containing Muller Hinton Agar (MHA) media by spreading. The petridisk is then incubated in anaerobic jar at $37^{\circ} \mathrm{C}$ for 24 hours. After incubation, an observation of the number of colonies grown on MHA was carried out and calculations with the Colony Forming Unit (CFU). The results data were then analyzed by the Kolmogorov-Smirnov Test, Levene's Test, One Way ANOVA, and Tukey HSD Post-Hoc Test.

\section{RESULTS}

The results of the study in the form of the number of Fusobacterium nucleatum bacteria colonies in MHA shown in Table 1.

Table 1. Mean values and standard deviations for the number of colonies of Fusobcaterium nucleatum bacteria

\begin{tabular}{|c|c|c|c|}
\hline Groups & N & Mean (colony) & Std. Deviation \\
\hline Positive Control & 6 & $105,50 \mathrm{CFU} / \mathrm{ml}$ & 3,728 \\
\hline I & 6 & $54,00 \mathrm{CFU} / \mathrm{ml}$ & 2,280 \\
\hline II & 6 & $28,17 \mathrm{CFU} / \mathrm{ml}$ & 1,472 \\
\hline III & 6 & $14,17 \mathrm{CFU} / \mathrm{ml}$ & 1,472 \\
\hline
\end{tabular}

Table description:

- Positive control $=\mathrm{Ca}(\mathrm{OH})_{2}$ - aquadest sterile

- Group I = combination of $\mathrm{Ca}(\mathrm{OH})_{2}$ - propolis $1: 1$

- Group II = combination of $\mathrm{Ca}(\mathrm{OH})_{2}$ - propolis $1: 1.5$

- Group III = combination of $\mathrm{Ca}(\mathrm{OH})_{2}$ - propolis $1: 2$

Based on the results of the study, it was found that the average number of $F$. nucleatum colonies in the treatment group was lower than the control group. The number of $F$. nucleatum colonies decreased along with the increasing composition of propolis extract in its 
combination with $\mathrm{Ca}(\mathrm{OH})_{2}$, as seen that the mean quantity of $F$. nucleatum colonies in group III was 14.17 $\mathrm{CFU} / \mathrm{ml}$ counted lower than group II which was 28.17 $\mathrm{CFU} / \mathrm{ml}$; the mean quantity of $F$. nucleatum colonies in group II was $28.17 \mathrm{CFU} / \mathrm{ml}$ counted lower than group I which was $54.00 \mathrm{CFU} / \mathrm{ml}$; and colonies in group I amounted to $54.00 \mathrm{CFU} / \mathrm{ml}$ counted lower than the control group which was $105.50 \mathrm{CFU} / \mathrm{ml}$. This means that the decrease in the number of $F$. nucleatum colonies is inversely proportional to the increase of propolis extract composition in its combination with $\mathrm{Ca}(\mathrm{OH})_{2}$. The lowest number of $F$. nucleatum colonies among the three treatment groups was in group III with a combination of $\mathrm{Ca}(\mathrm{OH})_{2}$ and propolis 1: 2 .
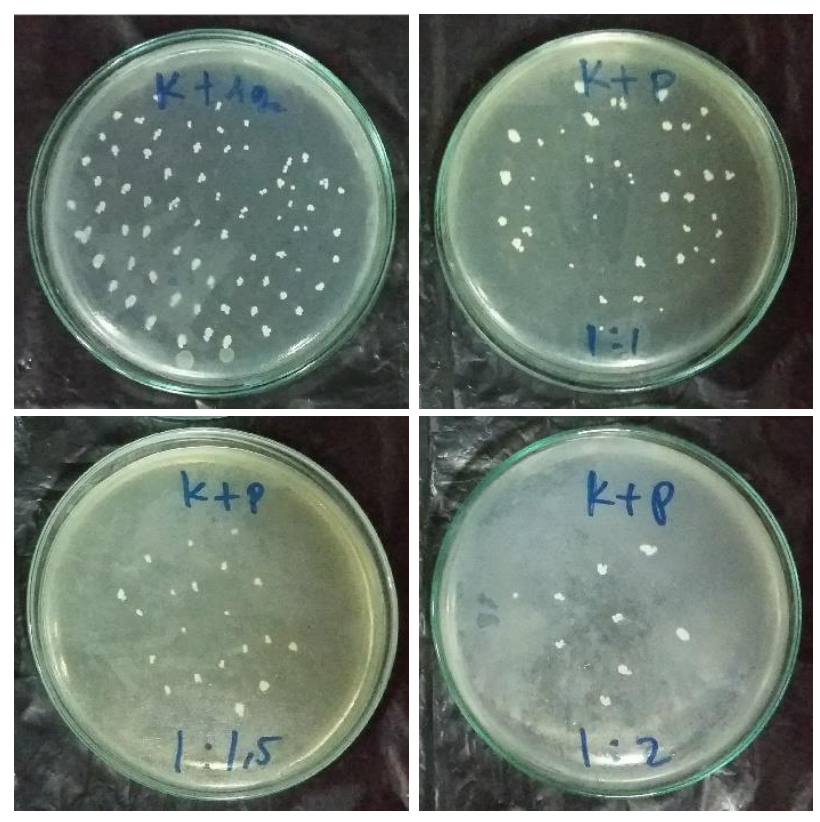

Figure 1. One of the six sample results

Normality tests were carried out in each research group using the Kolmogorov-Smirnov Test to see data distribution. The results of the normality test show a value of $p>0.05$ in all study groups which means that the data obtained from the results of the study are normally distributed. Next, the data variance homogeneity test was carried out in each study group using Levene's Test. Based on the results of the homogeneity test, obtained $\mathrm{p}>0.05$ which is $\mathrm{p}=0.138$ which means that the data variance is homogeneous.

After the normality and homogeneity of the data are met, the One Way ANOVA test is carried out to determine the difference in the calculated average across all sample groups. From the existing data, the results obtained $\mathrm{p}<0.05$, namely $\mathrm{p}=0,000$, which means that each treatment group has a significant difference.

Table 2. Data on the results of the Tukey HSD test

\begin{tabular}{|c|c|c|c|c|}
\hline & $\begin{array}{c}\text { Positive } \\
\text { Control }\end{array}$ & I & II & III \\
\hline $\begin{array}{c}\text { Positive } \\
\text { Control }\end{array}$ & - & $\mathrm{p}=0,000^{*}$ & $\mathrm{p}=0,000^{*}$ & $\mathrm{p}=0,000^{*}$ \\
\hline
\end{tabular}

\begin{tabular}{|c|c|c|c|c|}
\hline I & & - & $\mathrm{p}=0,000^{*}$ & $\mathrm{p}=0,000^{*}$ \\
\hline II & & & - & $\mathrm{p}=0,000^{*}$ \\
\hline III & & & & - \\
\hline
\end{tabular}

Table description :

- Positive control $=\mathrm{Ca}(\mathrm{OH})_{2}$ - sterile distilled water

- Group I = combination of $\mathrm{Ca}(\mathrm{OH})_{2}$ - propolis $1: 1$

- Group II = combination of $\mathrm{Ca}(\mathrm{OH})_{2}-$ propolis

$1: 1.5$

- Group III = combination of $\mathrm{Ca}(\mathrm{OH})_{2}$ - propolis $1: 2$

* significant difference (for $\mathrm{p}<0.05$ )

Data analysis was ended by looking at a comparison between samples using the Honestly Significant Difference (Tukey HSD) Test to determine whether or not there were significant differences between sample groups, as shown in Table 2.

\section{DISCUSSION}

The results showed that the addition of propolis to $\mathrm{Ca}(\mathrm{OH})_{2}$ was able to kill and inhibit colonization of $F$. nucleatum better than $\mathrm{Ca}(\mathrm{OH})_{2}$ without propolis. It was evident that the number of colonization of $F$. nucleatum in the control group was greater than in the three treatment groups of the combination of $\mathrm{Ca}(\mathrm{OH})_{2}$ and propolis. In addition, it was proven that the number of $F$. nucleatum colonies was inversely proportional to propolis extract composition in its combination with $\mathrm{Ca}(\mathrm{OH})_{2}$. These results can occur because in the combination of $\mathrm{Ca}(\mathrm{OH})_{2}$ and propolis, calcium salt compounds are formed with its active compounds derived from propolis extracts such as flavonoids, terpenoids and tannins (Leo, 2017). In the combination of $\mathrm{Ca}(\mathrm{OH})_{2}$ and propolis $1: 2$, there are more flavonoids, terpenoids and tannins than the combination of $1: 1.5$; as well as the combination of $\mathrm{Ca}(\mathrm{OH})_{2}$ and propolis $1: 1.5$ which contains more flavonoids, terpenoids and tannins when compared with a 1:1 combination as tested through phytochemical tests that were first carried out. Each active compound such as flavonoids, terpenoids and tannins has antibacterial power so that the more active content of the compound means the higher the antibacterial power, the less the number of colonies of bacteria formed $^{12-14}$.

According to Cushnie and Lamb (2005), flavonoids show antibacterial action through three main mechanisms, namely by inhibiting nucleic acid synthesis, function of cytoplasmic membranes and bacterial energy metabolism ${ }^{12}$. Kumar and Pandey (2013) also explained that flavonoids work as antibacterial through several cellular targets, more than one specific action. Molecular actions of flavonoids include forming complexes with bacterial cell proteins through nonspecific forces such as hydrogen bonds and hydrophobic effects, and by the formation of covalent bonds. The main performance of flavonoids is seen through ring $\mathrm{B}$ on flavonoids which 
play a role in hydrogen bonds with nucleic acid base structures in bacteria so that bacterial DNA and RNA synthesis is inhibited. The bond between flavonoids and bacterial cells will then deactivate the properties of microbial adhesin, enzymes, cell transport proteins, and so on related to the living needs of bacterial cells which will further inhibit their development to result in bacterial cell death ${ }^{15}$.

Terpenoids through sesquiterpenoid tt-farnesol work by increasing proton permeability in bacterial cell membranes which results in damage to the bacterial barrier membrane function. Damage to the function of bacterial membranes causes the diffusion of excess fluid into bacterial cells until the cell undergoes lysis ${ }^{13}$.

In addition to flavonoids and terpenoids, tannins also have antibacterial power through the action of catechins that are able to penetrate and interact with lipid bilayers, causing fusion of bacterial cell membranes, a process that results in material leakage and cell intramembrane aggregation which will further cause bacterial cell death $^{14}$

Various performance of propolis active compounds shows that propolis has good antibacterial power, in addition to its role as a carrier of $\mathrm{Ca}^{2+}$ and $\mathrm{OH}^{-}$ions resulted from the dissociation of $\mathrm{Ca}(\mathrm{OH})_{2}$ when both are combined. The antibacterial power of propolis combined with $\mathrm{Ca}(\mathrm{OH})_{2}$ was proven to be valid for $F$. nucleatum bacteria as seen through the results of research that showed that the treatment group with a combination of $\mathrm{Ca}(\mathrm{OH})_{2}$ and propolis left fewer $F$. nucleatum bacteria colonies compared to the control group namely $\mathrm{Ca}(\mathrm{OH})_{2}$ without propolis.

Based on the results of this research, concluded that the combination of $\mathrm{Ca}(\mathrm{OH})_{2}$ and propolis has an effective antibacterial effect on $F$. nucleatum with a ratio of $1: 2$ is more effective compared to $1: 1.5$ and $1: 1$. Therefore, a combination of $\mathrm{Ca}(\mathrm{OH})_{2}$ and propolis in a ratio of $1: 2$ can be further developed to be used later as an intracanal medication, in this case the dental root canal dressing, so that more optimal bacterial elimination occurs which simultaneously stimulates the regeneration of dental hard tissue.

\section{REFERENCES}

1. Yadav K, Prakash S. Dental caries: A Review. Asian $J$ Biomed Pharm Sci. 2016; 6(53):01-07. doi:10.15272/ajbps.v6i53.773

2. Torabinejad M, Walton RE. Endodontics Principles and Practice. 4th ed. (Saunders, ed.). Missouri: Elsevier Ltd;
2009.

3. Löst C. Quality guidelines for endodontic treatment: Consensus report of the European Society of Endodontology. Int Endod J. 2006; 39(12):921-930. doi:10.1111/j.1365-2591.2006.01180.x

4. Kim D, Kim E. Antimicrobial effect of calcium hydroxide as an intracanal medicament in root canal treatment: a literature review - Part I. In vitro studies. Restor Dent Endod. 2014; 39(4):241. doi:10.5395/rde.2014.39.4.241

5. Siqueira JF, Lopes HP. Mechanisms of antimicrobial activity of calcium hydroxide: A critical review. Int Endod J. 2009; 32(5):361-369. doi:10.1046/j.13652591.1999.00275.x

6. Ferreira NS, Martinho Frederico C, Cardoso FG., Nascimento GG, Carvalho CA., Valera MC. Microbiological Profile Resistant to Different Intracanal Medications in Primary Endodontic Infections. Am Assoc Endodontists. $\quad 2015 ; \quad 41(6): 824-830$. doi:10.1016/j.ijhydene.2015.04.002

7. Ferreira NS, Martinho FC, Cardoso FGR, Nascimento GG, Carvalho AT, Valera MC. Microbiological Profile Resistant to Different Intracanal Medications in Primary Endodontic Infections. 2015; 41(6). doi:10.1016/j.joen.2015.01.031

8. He Z, Huang Z, Zhou W, Tang Z, Ma R, Liang J. Antibiofilm Activities from Resveratrol against: Fusobacterium nucleatum. Front Microbiol. 2016; 7(JUL):1-9. doi:10.3389/fmicb.2016.01065

9. Fabris AS, Nakano V, Avila-Campos MJ. Bacteriological analysis of necrotic pulp and fistulae in primary teeth. $J$ Appl Oral Sci. 2014; 22(2):118-124. doi:10.1590/1678775720130358

10. Halim E, Hardinsyah, Sutandyo N, Sulaeman A, Artika M, Harahap Y. Kajian Bioaktif dan Zat Gizi Propolis Indonesia dan Brasil. J Gizi dan Pangan. 2012; 7(1):1-6.

11. Piana T, Gesteira MDFM, Carvalho E dos S, et al. Evaluation of the antimicrobial effect of calcium hydroxide combined to different vehicles. Rev Odonto Ciência. 2016; 31(2):89-94.

12. Cushnie TPT, Lamb AJ. Antimicrobial activity of flavonoids. Int J Antimicrob Agents. 2005; 26(5):343356. doi:10.1016/j.ijantimicag.2005.09.002

13. Jeon J, Pandit S, Xiao J, et al. Influences of trans-trans farnesol, a membrane-targeting sesquiterpenoid, on Streptococcus mutans physiology and survival within mixed-species oral biofilms. Int J Oral Sci. 2011; 3(2):98-106. doi:10.4248/IJOS11038

14. Slobodníková L, Fialová S, Rendeková K, Kováč J, Mučaji P. Antibiofilm Activity of Plant Polyphenols. Molecules. 2016; 21(12):1-15. doi:10.3390/molecules21121717

15. Kumar S, Pandey AK. Chemistry and Biological Activities of Flavonoids: An Overview. 2013; 2013(February 2014):1-16. doi:10.1155/2013/162750 